\title{
Bridging memories and transformative narratives: A visual and written response to Art-making with refugees and survivors by Sally Adnams Jones
}

Book Response: Art-making with refugees and survivors: Creative and transformative responses to trauma after natural disasters, war, and other crises, edited by Sally Adnams Jones. London, England: Jessica Kingsley Publishers, 2018, 336 pp., ISBN: 1785922386

Haley Toll, Memorial University of Newfoundland hrmtoll@mun.ca

Keywords: Community Arts; Refugees and Survivors; International Arts; Expressive and Creative Arts Therapies; Art Education; Transformative.

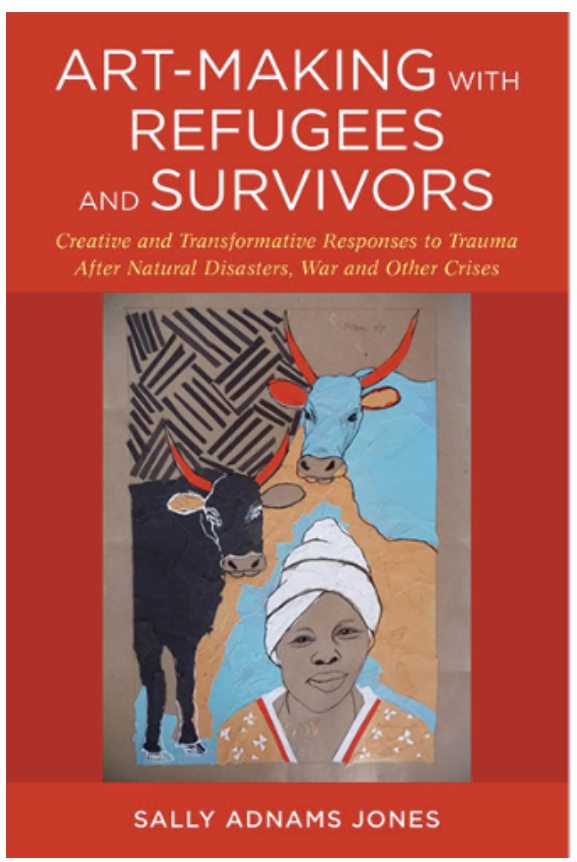

Figure 1. Book cover.

$\mathrm{T}$ he United Nations High Commissioner for Refugees (UNHCR, 2018) reports that the number of forcibly displaced people is at its highest since World War II. More than 68 million people were displaced at the end of 2017, due to natural disasters, persecution, and geopolitical conflicts and wars (UNHCR, 2018). A recent (2019) report by the World Refugee Council (WRC) argues, "Our world suffers not so much from a refugee crisis as from a political crisis - a deficit of leadership and vision and, most fundamentally, a shortfall of humanity and empathy." (WRC, 2019, p.1)

Sally Adnams Jones' book, Art-making with Refugees and Survivors (2018), is a compilation of stories from international authors, scholars, medical doctors, expressive art therapists, activists, and artists who share their experiences of building participatory community 
arts programs that support individuals who have experienced social and individual trauma. Adnams Jones believes that participatory art making in communities is healing and transformative, particularly during contemporary global challenges, such as the current refugee crises (UNHCR, 2018). Transformation, a central concept described in the book, involves different levels of "healing, learning, and evolving" (p. 10). Written in an accessible manner that aims to speak to readers from varied personal and professional backgrounds, Adnams Jones hopes that the book will change how creativity is viewed and experienced; that

creativity might be taken more seriously as a dignified transformative methodology for adults, adolescents, and children alike, from all walks of life, who are willing to tap into their own innate human creativity, which is the source of both their power and evolution." (p. 19)

The book fundamentally states, through a comprehensive synthesis of historical and contemporary research in the first four chapters, that expressing oneself creatively through artmaking can be an empowering, ethical, and supportive transformative process for people who are experiencing trauma, grief, and loss. Creative arts are described as all art forms, such as music, poetry, dance, drama, and visual arts. These are all considered "symbolic languages" of all individuals (Adnams Jones, 2018, p. 11). Expressive arts can impact individuals and larger societies by helping people and survivors from marginalized and oppressed communities share their stories from their own unique perspectives. Communicating stories through art can connect people from different backgrounds by fostering empathy and understanding. Furthermore, sharing evocative artwork can change prevalent discourses "by propagating visual memes" (p. 59) of multiple and marginalized viewpoints. In the introductory chapter, Adnams Jones shares her personal story about how art-making helped her recover from depression. When medication and talk therapy did not address her profound grief and isolation, Adnams Jones "...found the expressive arts... helped me resolve my past and come profoundly into the present, and then helped me actualize my future" (2018, p. 15). As an expressive arts therapist and scholar, Adnams Jones completed her doctorate degree in Art Education at the University of Victoria, Canada.

The five subsequent chapters contain long and rich narratives that detail five contributing authors' evolutions towards their community arts vocation. Each chapter ends with a synopsis of practical learnings generated from their experiences. To consolidate their lived experiences into chapters, the authors employ "...diverse genres, from actual ethnography, non-fiction, poetry, journaling, richly humorous metaphor and autobiographical memoir" (Adnams Jones, 2018, pp. 289-290). The first contributing author, Lily Yeh, describes building community art gardens with the development of the Barefoot Artists Organization in Philadelphia, Kenya, and Rwanda. In the next chapter, Carol Hofmeyr discusses the power of art in developing a meaningful community space to express and communicate a group of women's shared stories in the Keiskamma Trust Art Project. In the subsequent chapter, Max Levi Fender situates the reader into different locations across the world, with narratives about the Artolution Projects in Jordan, Greece, France, Syria, Palestine, Israel, and India. Finally, through stories and poetic dialogue, Paul Hogan imaginatively illustrates the healing potential of magical, artistic, and peaceful spaces in the development of the Spiral Garden in Canada and the Butterfly Peace Garden in Sri Lanka. Adnams Jones finishes the compilation of narratives by sharing her experience of learning from a Coast Salish Elder of Canada about carving totem poles. The brief descriptions in this review do not capture the depth, nuance, artistry, and personal voice in each chapter, which are worth reading in detail. The center of the book contains coloured images that portray the vibrant and textured artwork created and action-shots of child, adolescent, and adult artists engaging in art-making, advocacy, and play. As 
a visually-focused painter and artist, I found that the images were helpful in understanding the projects described.

All of the stories entail cross-cultural experiences of people from diverse backgrounds connecting to one another through creating together. It is important to mention that the artistscholars mostly come from developed countries and/or from educated backgrounds, with a particular theoretical perspective on art. The ontologies and epistemologies are influenced by community-arts, critical, feminist, transformative, post-colonial, and post-modern literature in the field of education and social work, such as writings by Boal (1979), Friere (1970), and Greene $(1977 ;$ 1995). In addition, psychological theories and research on arts and well-being were influenced by authors like McNiff (1992; 2004), Jung (2009), Maslow (1954), and Csikszentmikalyi (1990; 1996), Van der Kolk (2014), and Frankl (2006), among others. Therefore, the literature referenced is mostly Western-influenced. The authors note feelings of inadequacy when encountering the experiences of people in low-resourced locations, such as inner-cities, slums, and overcrowded and isolated refugee camps, knowing that they have the privilege to leave when the arts project is complete. The historical and colonial dynamic of Northern-hemisphere countries helping Southern-hemisphere countries with relief and development work is acknowledged by the authors. Adnams Jones does not want the book to be "trauma-tourism by the more fortunate" (p. 10) and endeavors to convey the strength, resiliency, and creativity of the individual participant artists in the projects. The authors acknowledge the potential to re-perpetrate colonial trauma and dynamics, while expressing their reflexive intention not to engage in this destructive dynamic (Kapitan, 2015; Potash, Bradot, Moon, Napoli, Lyonsmith, \& Hamilton, 2017).

In light of the theme that creating arts can cultivate transformational self-awareness and emotional resonance, I made a response-artwork in Figure 2 that details my experience of the book. While I was reading insights from authors, vivid memories emerged from my past work in Botswana. The reflexive artwork details one experience. It portrays a conté self-portrait in the middle of two colleagues who had joined to help me paint a mural for a social enterprise in a village outside of Gaborone. The reference photograph was taken seven years ago during the final week of my year-long stay, working as a psychosocial support advisor with an organization that supports orphans and vulnerable youth. During the final weeks, I remembered frantically running from one task to the next. The moment depicted in Figure 2 is when a few colleagues, youth, and I painted outside. Painting together outside to music created a quiet and intimate opportunity to connect through making together. The faded black-and-white sketchiness of the figurative drawing represents my growing understanding of the work while I was there. 


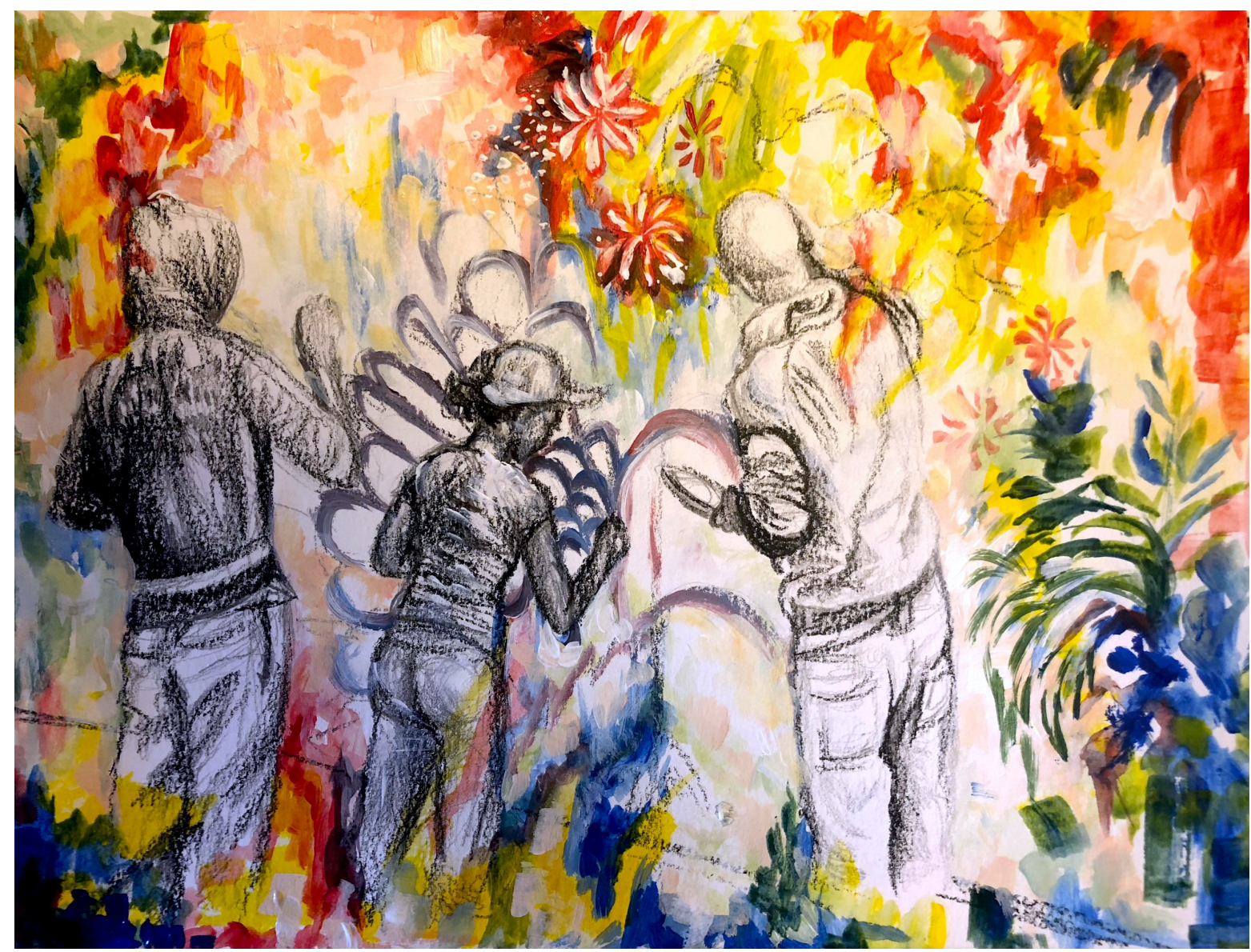

Figure 2. Toll, H. (2019). Vivid moments and memories. Multimedia on watercolour paper. Edmonton, AB: Private collection.

The brightly-coloured painterly gestures in Figure 2 represent the rich and informative stories from the book, which help to bring context, understanding, ethical considerations, and new insight to my previous experience. Despite the effective pre-departure and in-country training, I wish that I had read a book like this one before my year in Botswana: specifically related to community transformative arts. The book highlights the value of creativity to our humanity and well-being. Thus, reading this text would have helped me be more innovative and knowledgeable seven years ago. The author hopes that the work will "...reach all those who need it, for their health, happiness, and transformation" (Adnam Jones, 2018, p. 19). I recommend it to anyone who is working in the creative arts in community and international development field, particularly with people who have experienced trauma, marginalization, displacement, and oppression. This includes nurses, doctors, art therapists, psychologists, art educators, art educators, and artists who are hired to do community arts work. The volume would also be of interest to international nongovernmental and non-profit organizations. Due to its open and accessible nature, the book could be included as a course-text in an introductory course to community arts counselling, intercultural arts education, and international art therapy.

Adnams Jones (2018) hopes that, “...by gathering these stories, valuable experiences may be shared with all those interested in moving beyond art's decorative aesthetic, and its market commodification, into a more transformative practice of conscious creativity" (p. 19). This book 
makes an important contribution to expressive arts and community arts literature. Highlighted by my response art to the book, I believe that reading Adnams Jones' robust introductory chapters and the unique life stories of the contributing authors, with care and curiosity, will be both illuminating and transformative for the reader.

\section{References}

Boal, A. (1979). Theatre of the oppressed. New York, NY: Theatre Communications Group.

Csikszentmikalyi, M. (1990). Flow: The psychology of optimal experience. New York, NY: Harper Perennial Modern Classics.

Csikszentmikalyi, M. (1996). Creativity: Flow and psychology of discovery and invention. New York, NY: Harper Collins.

Frankl, V. (2006). Man's search for meaning. Boston, MA: Beacon Press.

Freire, P. (1970). Pedagogy of the oppressed. New York, NY: Bloomsbury.

Greene, M. (1977). Imagination and aesthetic literacy. Art Education, 20(6), 14-20.

Greene, M. (1995). Releasing the imagination: Essays on Education, the arts, and social change. San Francisco, CA: John Wiley \& Sons.

Jung, C. G. (2009). The red book: Liber Novus. New York, NY: W. W. Norton.

Kapitan, L. (2015). Social action in practice: Shifting the ethnocentric lens in cross-cultural art therapy encounters. Art Therapy: Journal of the American Art Therapy Association, 32(3), 104111.

Maslow, A. H. (1954). Motivation and personality. New York, NY: Van Nostrand-Reinhold.

McNiff, S. (1992). Art as medicine: Creating a therapy of the imagination. Boston, MA: Shambhala Publications.

McNiff, S. (2004). Art heals: How creativity cures the soul. Boston, MA: Shambhala.

Potash, J. S., Bradot, H., Moon, C. H., Napoli, M., Lyonsmith, A., \& Hamilton, M. (2017). Ethical implications of cross-cultural international art therapy. The Arts in Psychotherapy, 56, 74-81. Doi: http://dx.doi.org/10.1016/j.aip.2017.08.005

United Nations High Commissioner for Refugees (2018). Global trends: Forced displacement in 2017. Geneva, Switzerland: UNHCR. Retrieved from www.unhcr.org/en-us/statistics/ unhcrstats/5b27be547/unhcrglobal-trends-2017.html. 
Van der Kolk, B. (2014). The body keeps the score: Brain, mind, and body in the healing of trauma. New York, NY: Viking Publishers.

World Refugee Council. (2019). A call to action: Transforming the global refugee system. Retrieved on May 30, 2019 from https://www.cigionline.org/sites/default/files/documents/WRC Call to Action.pdf 